\title{
Publisher Correction: Short-segment posterior fixation with index level screws versus long-segment posterior fixation for thoracolumbar spine fracture: angle of correction and pain
}

\author{
Ahmed M. Sallam', Walid A. Abdel Ghany ${ }^{2,3^{*}}$, Ali Kotb Ali², Mohamed A. Habib², Ahmed F. Toubar², \\ Mohamed S. Kabil ${ }^{2}$, Ahmed Abdel Barr Salem², Sherif H. Abouzeid Mourad ${ }^{2}$ and Mohamed A. Nada ${ }^{2}$
}

\section{Publisher Correction}

In the publication of this article [1], unfortunately not the latest version of the Declarations section has been published. The publisher apologizes to the readers and authors for the inconvenience. This has now been included in this Publisher Correction. Please see the final version of the Declaration section below:

\section{Acknowledgements}

No other person contributed to this article

\section{Funding}

All patients included in this study were operated under the cover of the Egyptian Health Insurance System. The procedures were done in the Ain Shams University Hospitals and the Arab Contractors Medical Center.

\section{Availability of data and materials}

Readers can find the supporting data of this study in the following link: https://doi.org/10.5281/zenodo.1210185.

\footnotetext{
Authors' contributions

Study conception and design: Ahmed M.Sallam, Ali Kotb Ali, Mohamed A. Habib. Acquisition of data: Ahmed M.Sallam, Walid A. Abdel Ghany, Ahmed F. Toubar, Sherif H. Abouzeid Mourad, Ahmed Abdel Barr Salem, Mohamed S. Kabil. Analysis and interpretation of data: Ahmed M.Sallam, Mohamed A. Nada. Drafting of manuscript: Walid A. Abdel Ghany, Mohamed A. Nada. Revision: Walid A. Abdel Ghany.
}

\section{Ethics approval and consent to participate}

The study design and statistical methodology was approved by the Ain Shams University Ethical Committee Review. Reference No. G10800. Informed consents were obtained for all patients included in this study for participation.

\footnotetext{
* Correspondence: Wghany@med.asu.edu.eg

2Department of Neurosurgery, Ain Shams University, 27A, Baghdad St. El

Korba, Roxy, Heliopolis, Cairo, Egypt

${ }^{3}$ Cairo, Egypt

Full list of author information is available at the end of the article
}

\section{Consent for publication}

This study reported no personal data for any patients; informed consents were obtained for all patients included in this study to publish the results.

\section{Competing interests}

The authors declare that they have no competing interests.

\section{Author details}

1Department of Neurosurgery, Arab Contractors Medical Center (A.C.M.C) Cairo, Egypt. ${ }^{2}$ Department of Neurosurgery, Ain Shams University, 27A, Baghdad St. El Korba, Roxy, Heliopolis, Cairo, Egypt. ${ }^{3}$ Cairo, Egypt.

\section{Received: 8 October 2018 Accepted: 8 October 2018}

Published online: 31 October 2018

\section{Reference}

1. Sallam AM, Abdel Ghany WA, Ali AK, et al. Short-segment posterior fixation with index level screws versus long-segment posterior fixation for thoracolumbar spine fracture: angle of correction and pain. Egypt J Neurosurg. 2018;33:11 https://doi.org/10.1186/s41984-018-0012-9.
Springer Open

(c) The Author(s). 2018 Open Access This article is distributed under the terms of the Creative Commons Attribution 4.0 International License (http://creativecommons.org/licenses/by/4.0/), which permits unrestricted use, distribution, and reproduction in any medium, provided you give appropriate credit to the original author(s) and the source, provide a link to the Creative Commons license, and indicate if changes were made. 